\title{
Anesthetic Pharmacology of the Mint Extracts L-Carvone and Methyl Salicylate
}

\author{
Robert J. Brosnan ${ }^{\mathrm{a}}$ Kimberly Ramos $^{\mathrm{b}}$ Antonio Jose de Araujo Aguiar ${ }^{\mathrm{c}}$ \\ Alessia Cenani $^{\mathrm{a}}$ Heather K. Knych ${ }^{\mathrm{d}}$ \\ ${ }^{a}$ Department of Surgical and Radiological Sciences, School of Veterinary Medicine, University of California, Davis, \\ CA, USA; bepartment of Animal Biology, University of California, Davis, CA, USA; 'Departamento de Cirurgia \\ Veterinária e Reprodução Animal, Universidade Estadual Paulista, Botucatu, Brazil; ${ }^{d}$ California Animal Health and \\ Food Safety Lab, Department of Molecular Biosciences, School of Veterinary Medicine, University of California, \\ Davis, CA, USA
}

\section{Keywords}

Anesthesia - Euthanasia $\cdot \gamma$-Amino butyric acid type .

$\mathrm{N}$-Methyl-D-aspartate $\cdot$ Voltage-gated sodium channel

\begin{abstract}
Introduction: Hydrocarbons with sufficient water solubility allosterically modulate anesthetic-sensitive ion channels. Mint extracts L-carvone and methyl salicylate water solubility exceeds modulation cutoff values for $\gamma$-amino butyric acid type $\mathrm{A}\left(\mathrm{GABA}_{\mathrm{A}}\right)$ receptors, $\mathrm{N}$-methyl-D-aspartate (NMDA) receptors, and type- 2 voltage-gated sodium $\left(\mathrm{Na}_{v} 1.2\right)$ channels. We hypothesized that mint extracts modulate these channels at concentrations that anesthetize rats. Methods: Channels were expressed separately in frog oocytes and studied using 2-electrode voltage clamp techniques at drug concentrations up to $10 \mathrm{~mm}$. Normalized current effects were fit to Hill equations. Mint compounds were formulated in a lipid emulsion and administered IV to rats. When unresponsive to the tail clamp, rats were exsanguinated, and plasma drug concentrations were measured. Results: Both mint compounds caused concentration-dependent inhibition of all channels except for methyl salicylate which inhibited $G A B A_{A}$ receptors at low concentrations and potentiated
\end{abstract}

karger@karger.com www.karger.com/pha

Karger $\stackrel{\text { ' }}{5}$

GOPEN ACCESS
(C) 2022 The Author(s)

Published by S. Karger AG, Basel

This is an Open Access article licensed under the Creative Commons Attribution-NonCommercial-4.0 International License (CC BY-NC) (http://www.karger.com/Services/OpenAccessLicense), applicable to the online version of the article only. Usage and distribution for commercial purposes requires written permission. at high concentrations. Plasma drug concentrations in anesthetized rats were $7.9 \mathrm{mM}$ for L-carvone and $2.7 \mathrm{mM}$ for methyl salicylate. This corresponded to $\geq 53 \%$ NMDA receptor inhibition and $\geq 78 \% \mathrm{Na}_{\mathrm{v}} 1.2$ channel inhibition by both compounds and $30 \%$ potentiation of $\mathrm{GABA}_{\mathrm{A}}$ receptors by methyl salicylate. Conclusion: L-Carvone and methyl salicylate allosterically modulate cell receptor targets important to molecular actions of conventional anesthetics at concentrations that also induce general anesthesia in rats.

(c) 2022 The Author(s)

Published by S. Karger AG, Basel

\section{Introduction}

Common ion channel targets for anesthetics include $\gamma$-amino butyric acid type $\mathrm{A}\left(\mathrm{GABA}_{\mathrm{A}}\right)$ receptors, $\mathrm{N}$ methyl-D-aspartate (NMDA) receptors, and type-2 voltage-gated sodium $\left(\mathrm{Na}_{\mathrm{v}} 1.2\right)$ channels. Many injectable anesthetics exhibit high-affinity for only one of these receptor targets. As examples, anesthetic effects of propofol are primarily due to $\mathrm{GABA}_{\mathrm{A}}$ receptor potentiation, ketamine effects from NMDA receptor inhibition, and lidocaine effects from sodium channel blockade, including $\mathrm{Na}_{\mathrm{v}} 1.2$ channels. In contrast, inhaled anesthetics, such as isoflu- 
rane, sevoflurane, and desflurane, exhibit comparatively low receptor affinity but simultaneously modulate a large number of anesthetic-sensitive cell receptors and channels - including $\mathrm{GABA}_{\mathrm{A}}, \mathrm{NMDA}$, and $\mathrm{Na}_{\mathrm{v}} 1.2$ - at concentrations relevant to clinical anesthesia $[1,2]$.

Nonselective, low-affinity interactions with anesthetic-sensitive ion channels are not limited to conventional inhaled agents. Presumably by competing with water molecules occupying allosterically active amphipathic binding pockets in the protein, all hydrocarbons appear able to modulate anesthetic-sensitive ion channel currents, provided that the molar water solubility of the hydrocarbon exceeds that of the ion channel's measured solubility cutoff value [3-5]. The molar water solubility cutoff is defined as that minimum molar water solubility required of an amphipathic hydrocarbon to be able to allosterically modulate receptor function at sufficiently high concentrations (up to concentrations that equal the molar water solubility of the hydrocarbon). The average molar water solubility cutoff is $0.12 \mathrm{mM}$ for $\mathrm{GABA}_{\mathrm{A}}$ receptors, $1.1 \mathrm{mM}$ for NMDA receptors, and $1.4 \mathrm{mM}$ for $\mathrm{Na}_{\mathrm{v}} 1.2$ channels $[4,5]$.

Terpenoids and salicylate esters are a large and diverse group of naturally occurring plant compounds, many of which have water solubility in excess of the cutoff values for common anesthetic-sensitive channels and receptors. Chemically, the "backbone" of terpenoid molecules is formed by linking 5-carbon units of isoprene (2-methylbuta-1,3-diene) that can subsequently undergo cyclization and cross-linking as per the isoprene rule and addition of oxygen-containing functional groups. Terpenoids are classified according to the number of isoprene units that form their linear backbone: hemiterpenoids $\left(\mathrm{C}_{5} \mathrm{H}_{8}\right)$ contain 1 isoprene unit, monoterpenoids $\left(\mathrm{C}_{10} \mathrm{H}_{16}\right)$ contain 2 units, and sesquiterpenoids $\left(\mathrm{C}_{15} \mathrm{H}_{24}\right)$ contain 3 units [6]. Salicylate, 2-hydroxybenzoic acid $\left(\mathrm{C}_{7} \mathrm{H}_{6} \mathrm{O}_{3}\right)$, is formed in plants as a metabolite of cinnamic acid via the phenylpropanoid pathway. Condensation of the salicylate carboxylic acid group with an alcohol creates a salicylate ester [7].

$\mathrm{L}-$ Carvone is a monoterpene found as an essential oil component of spearmint (Mentha spicata). Methyl salicylate is found as an essential oil component of wintergreen (Gaultheria spp.). The Chemical Abstracts Service database of the American Chemical Society lists a calculated molar water solubility for L-carvone of $7.8 \mathrm{mM}$ and for methyl salicylate of $21 \mathrm{mM}$ at $\mathrm{pH}=7$. Because both of these compounds have molar water solubilities higher than the cutoff values for $\mathrm{GABA}_{\mathrm{A}}$ and NMDA receptors and $\mathrm{Na}_{\mathrm{v}} 1.2$ channels, both L-carvone and methyl salicy- late should exhibit low-affinity interactions at sufficiently high concentrations and be able to modulate function of all of 3 anesthetic-sensitive ion channels.

We hypothesized that L-carvone and methyl salicylate each cause dose-dependent modulation of ion channel currents when $\mathrm{GABA}_{\mathrm{A}}$ and NMDA receptors and $\mathrm{Na}_{\mathrm{v}} 1.2$ channels are separately expressed in oocytes. If either compound is an anesthetic and not a convulsant, it should potentiate $\mathrm{GABA}_{\mathrm{A}}$ receptors or inhibit NMDA receptors or inhibit $\mathrm{Na}_{\mathrm{v}} 1.2$ channel currents. For compounds producing anesthetic-like modulation of ion channels, we predicted general anesthetic activity in vivo at plasma concentrations that correspond to their anesthetic-sensitive receptor effects in vitro.

\section{Methods}

In vitro Electrophysiology Studies

Oocyte Collection and Channel Expression

Ovaries removed from sexually mature Xenopus laevis frogs were bluntly dissected to remove surrounding connective tissue and then digested with $0.2 \%$ type I collagenase in an oocyte Ringer's solution. Once free from thecal cells and connective tissue, individual oocytes were rinsed, sorted, and stored in a modified Barth's solution [8-11].

Plasmids containing channel subunit genes were provided as a generous gift from Dr. Adron Harris. All genes were sequenced and compared to the National Center for Biotechnology Information nucleotide data to confirm gene identity. Heteromeric GAB$A_{A}$ receptors were expressed in oocytes by blind intranuclear injection of 1 ng DNA encoding the human $\alpha_{1}$ (GABRA1) and rat $\beta_{2}$ (GABRB2) subunits in a 1:1 ratio. NMDA receptors were expressed by intracytoplasmic injection of $5 \mathrm{ng}$ RNA encoding rat NR1 (GRIN1) and rat NR2a (GRIN2A) subunits in a 1:1 ratio. $\mathrm{Na}_{\mathrm{v}} 1.2$ channels were expressed by injection of $5 \mathrm{ng}$ RNA encoding the human SCN2A gene.

\section{GABAA Receptor Experiments}

Two-electrode voltage clamp studies were carried out in a 0.25 $\mathrm{mL}$ linear perfusion chamber. Perfusates were delivered by using a syringe pump at $1.5 \mathrm{~mL} / \mathrm{min}$ using gastight glass syringes and polytetrafluoroethylene tubing.

Oocytes were impaled by two $3 \mathrm{M} \mathrm{KCl-filled} 0.2-1 \mathrm{M} \Omega$ borosilicate glass electrodes (KG-33; King Precision Glass, Claremont, CA, USA) connected to separate headstages (Axon Instruments HS2A; Molecular Devices, San Jose, CA, USA) through which voltage was clamped at $-80 \mathrm{mV}$ and current was passed via a computer-controlled amplifier (Axon Instruments GeneClamp 500B; Molecular Devices). Oocytes were perfused with frog Ringer's (FR) solution containing $115 \mathrm{mM} \mathrm{NaCl}, 2.5 \mathrm{mM} \mathrm{KCl}, 1.8 \mathrm{mM} \mathrm{CaCl}_{2}$, and $10 \mathrm{mM}$ HEPES prepared from ACS-grade chemicals and 18.2 $\mathrm{M} \Omega$ $\mathrm{H}_{2} \mathrm{O}$, filtered and $\mathrm{pH}$ adjusted to 7.4. At 5-min intervals, the solution was switched to FR containing $50 \mu \mathrm{M}$ GABA; this concentration produces a chloride current equal to $35-40 \%$ of a maximum GABA agonist response. After $30 \mathrm{~s}$, the perfusate was switched back to FR solution. This process was repeated until a stable base- 
line response was achieved. Next, FR containing either L-carvone (99\%; Sigma-Aldrich, St. Louis, MO, USA) or methyl salicylate ( $\geq 99 \%$; Sigma-Aldrich) at the test concentration was used to perfuse the oocyte for $1.5 \mathrm{~min}$, and then the oocyte was perfused with $\mathrm{FR}+\mathrm{GABA}$ solution containing this same drug and concentration for $30 \mathrm{~s}$. Last, the solution was switched back to FR to wash out the drug for $5 \mathrm{~min}$, and then FR + GABA was perfused for $30 \mathrm{~s}$ to confirm that the post-drug agonist response had returned to within $10 \%$ of the pre-drug response. Uninjected oocytes served as negative controls. Only one drug and concentration were studied per oocyte.

\section{NMDA Receptor Experiments}

Studies were carried out using equipment identical to that described for $\mathrm{GABA}_{\mathrm{A}}$ receptors. Transmembrane potential was clamped at $-80 \mathrm{mV}$, and oocytes were perfused with a bariumcontaining FR solution (Ba-FR) which substituted equimolar $\mathrm{BaCl}_{2}$ for calcium salts and contained $0.1 \mathrm{~mm}$ EGTA as a calcium chelator. After $5 \mathrm{~min}$, the perfusate was changed for $30 \mathrm{~s}$ to barium FR containing $0.1 \mathrm{mM}$ glutamate plus $0.01 \mathrm{mM}$ glycine (Ba-FREG) as receptor agonists which produce an NMDA receptor current $>99 \%$ of the maximal response. Next, Ba-FR containing the study drug was perfused for $5 \mathrm{~min}$ and then switched to Ba-FREG containing the same test article for $30 \mathrm{~s}$. The drug was then washed out with a 5-min perfusion of Ba-FR followed by a 30-s exposure to $\mathrm{Ba}-\mathrm{FREG}$ to confirm post-drug currents had returned to within $10 \%$ of pre-drug values.

\section{$\mathrm{Na}_{\mathrm{v}} 1.2$ Channel Experiments}

Using the same equipment as above, oocytes were perfused with FR and clamped at $-80 \mathrm{mV}$ transmembrane potential. Every $2 \mathrm{~min}$, a 6-s step potential to $0 \mathrm{mV}$ was applied to open the channel; this was repeated until baseline responses stabilized. Next, FR containing the test drug was perfused for 2 min followed by another 6-s step voltage change to $0 \mathrm{mV}$. Finally, FR was perfused for $5 \mathrm{~min}$ to wash out the drug, and another 6-s step clamp to $0 \mathrm{mV}$ was applied to confirm that post-drug currents had returned to within $10 \%$ of pre-drug values.

\section{Data Analysis}

The change in whole cell peak current before and during agonist exposure (for $\mathrm{GABA}_{\mathrm{A}}$ and NMDA receptors) or before and during the voltage step clamp (for $\mathrm{Na}_{\mathrm{v}} 1.2$ channels) was measured in the tracings immediately before and during drug exposure. Percent change in current was calculated as follows:

$$
\% \Delta=\frac{I_{\mathrm{D}}-I_{\mathrm{B}}}{I_{\mathrm{B}}} \times 100,
$$

where $I_{\mathrm{B}}$ is the baseline pre-drug current peak and $I_{\mathrm{D}}$ is the drug current peak.

For each drug and ion channel, data were fit to a Hill equation using nonlinear regression with sequential quadratic programming and bootstrap estimates of parameter standard errors (SPSS, v. 27; IBM, Armonk, NY, USA). In the model, maximum drug inhibition $\left(I_{\max }\right)$ was constrained to not be $<-100 \%$. Initial parameter estimates were seeded with values based on visual inspection of respective dose-response curves in order to facilitate model convergence.

Anesthetic Pharmacology of Mint

Extracts

\section{In vivo Anesthesia Studies}

Pilot Experiments

Solutions of $10 \%(\mathrm{v} / \mathrm{v})$ L-carvone or methyl salicylate were prepared sterilely in $20 \%$ intralipid (Fresenius Kabi, Lake Zurich, IL, USA). Lateral tail vein catheters were placed in twenty-one 69-dayold, male, Sprague Dawley rats weighing $291 \pm 17$ (mean \pm SD) grams. Each rat received a single intravenous bolus injection of Lcarvone solution $(0.2$ or $0.4 \mathrm{~mL})$, methyl salicylate solution $(0.1$, $0.15,0.2$, or $0.4 \mathrm{~mL}$ ), or a $1: 1$ mixture of the L-carvone and methyl salicylate solutions over $15 \mathrm{~s}$. Because L-carvone density is 0.9673 $\mathrm{g} / \mathrm{cm}^{3}$ at $25^{\circ} \mathrm{C}, 0.2 \mathrm{~mL}$ and $0.4 \mathrm{~mL}$ of solution contained $19 \mathrm{mg}$ and $39 \mathrm{mg}$ of L-carvone, respectively [12]. The density of methyl salicylate is $1.1798 \mathrm{~g} / \mathrm{cm}^{3}$ at $25^{\circ} \mathrm{C}$; hence, $0.2 \mathrm{~mL}$ and $0.4 \mathrm{~mL}$ of solution contained $24 \mathrm{mg}$ and $47 \mathrm{mg}$ of methyl salicylate, respectively [13].

Spontaneous motor activity and loss-of-righting reflex was assessed at 5- to 10-s intervals, and nociception response to an alligator clamp applied to the tail was tested if the righting reflex was absent. Animals administered the lower doses of L-carvone, methyl salicylate, and the drug mixture were recovered and returned to the vivarium. Animals were weighed 24 and $48 \mathrm{~h}$ after the study and then euthanized for gross pathology examination.

\section{Plasma Drug Concentrations in Anesthetized Rats}

Lateral tail veins were catheterized in eight, 70-day-old, male, Sprague Dawley rats weighing $309 \pm 6$ g. A 10\% solution of L-carvone or methyl salicylate in $20 \%$ intralipid was each administered IV to 8 rats ( 4 animals per drug treatment) by using a syringe pump at a rate of $12 \mathrm{~mL} / \mathrm{h}$. When rats lost their righting reflex and were unresponsive to a tail clamp, a midline laparotomy was performed, the abdominal aorta catheterized, and the rat exsanguinated. Blood was collected in a heparin tube and centrifuged; plasma was separated and stored in cryogenic tubes at $-80^{\circ} \mathrm{C}$ until analysis.

\section{Measurement of Drug Concentrations}

Serum calibrations were prepared by dilution of working standard solutions of methyl salicylate and L-carvone with drug-free rat serum (Innovative Research, Novi, MI, USA) to concentrations ranging from 0.05 to $500 \mu \mathrm{g} / \mathrm{mL}$. Calibration curves and negative control samples were prepared fresh for each quantitative assay. In addition, quality control samples (drug-free rat serum fortified with analyte at 3-4 concentrations within the standard curve) were included as an additional check of accuracy.

Prior to analysis, $100 \mu \mathrm{L}$ of each serum sample was diluted with $100 \mu \mathrm{L}$ of acetonitrile (ACN):1 M acetic acid (9:1, v:v) and $50 \mu \mathrm{L}$ of methanol to precipitate proteins. The samples were vortexed for 2 min to mix, refrigerated for $20 \mathrm{~min}$, vortexed for an additional 1 min, centrifuged $(4,300 \mathrm{rpm} / 3,102 \mathrm{~g})$ for $10 \mathrm{~min}$ at $4^{\circ} \mathrm{C}$, and $10 \mu \mathrm{L}$ injected into the liquid chromatography tandem mass spectrometry system.

Quantitative analysis was performed on an LTQ XL Orbitrap mass spectrometer (Thermo Scientific, San Jose, CA, USA) coupled with a Waters Acquity UPLC (Milford, MA, USA). The system was operated at a resolution of $15,000(M / \Delta M$, at full width at half maximum of the mass peaks) using positive electrospray ionization $(\mathrm{ESI}[+])$. Detection and quantification were conducted using full-scan accurate mass from 145 to $160(\mathrm{~m} / \mathrm{z})$. The responses were plotted using a 20-ppm data window for methyl salicylate (mass-to-charge ratio $153.05443[\mathrm{~m} / \mathrm{z}]$ ) and L-carvone (mass-tocharge ratio $151.11160[\mathrm{~m} / \mathrm{z}])$. The spray voltage was $3,500 \mathrm{~V}$, and 
Fig. 1. Sample electrophysiology tracings for GA$\mathrm{BA}_{\mathrm{A}}$ receptors $(\mathbf{A}), \mathrm{NMDA}$ receptors $(\mathbf{B})$, and $\mathrm{Na}_{\mathrm{v}} 1.2$ channels $(\mathbf{C})$ before, during, and after exposure to $1 \mathrm{mML}$-carvone. Tracings for methyl salicylate exposures were qualitatively similar. $\mathrm{GABA}_{\mathrm{A}}$, $\gamma$-amino butyric acid type A; NMDA, N-methyl-Daspartate; $\mathrm{Na}_{\mathrm{v}} 1.2$, type-2 voltage-gated sodium.
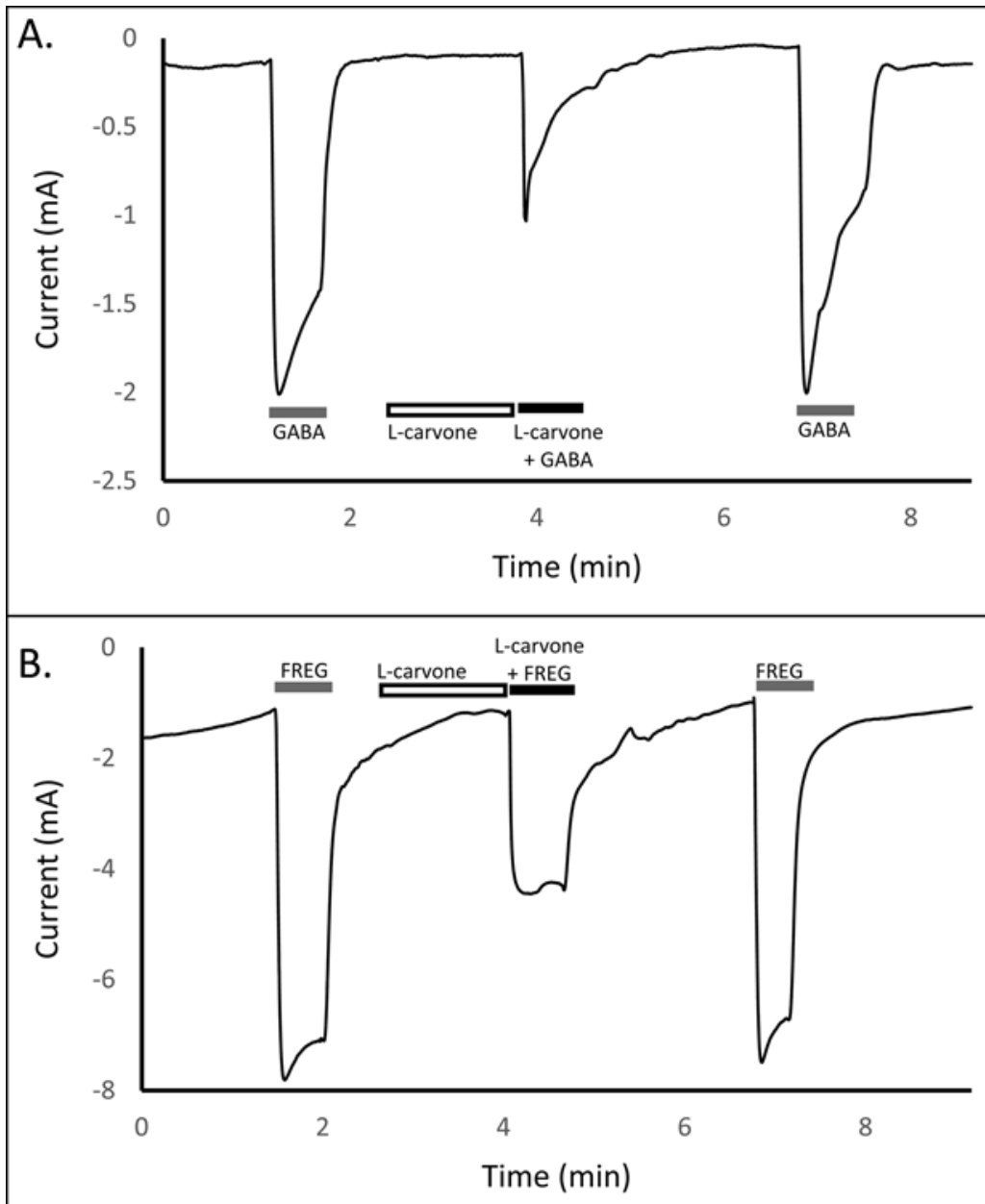

C.

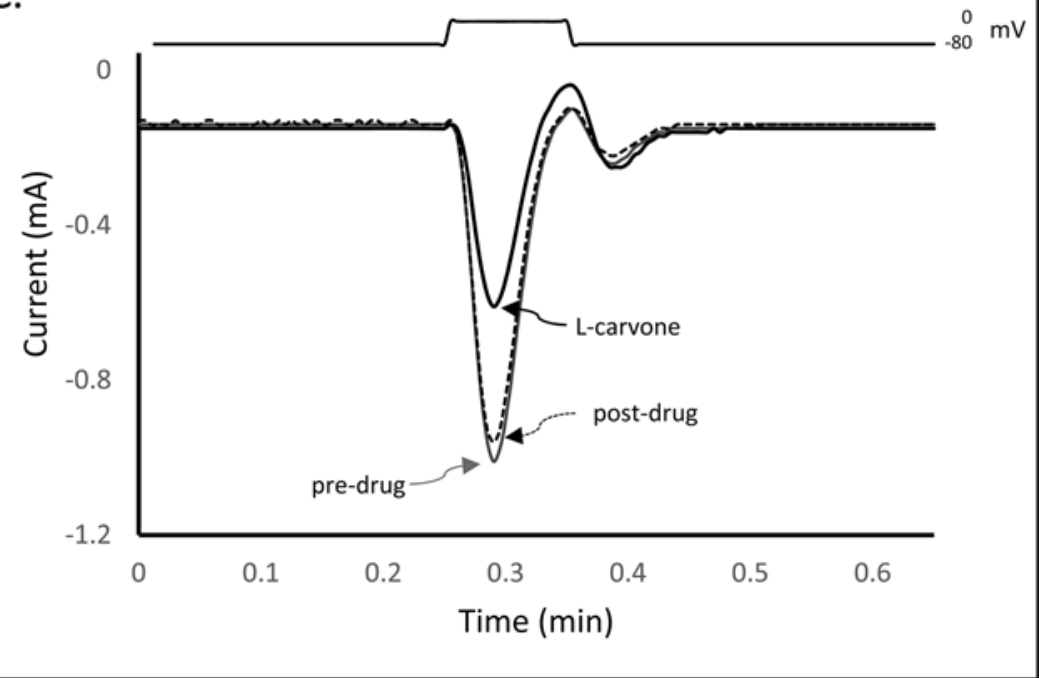


Fig. 2. Linear-log plot of the percent current change from baseline of $\mathrm{GABA}_{\mathrm{A}}$ receptors exposed to L-carvone. Data are from 4-8 oocytes at each concentration. The solid line is the best fit to the Hill equation:

$-100 \frac{C^{1.3}}{\left(7.2 \times 10^{-5}\right)+C^{1.3}}$,

where $C$ is the L-carvone concentration. $\mathrm{GABA}_{\mathrm{A}}, \gamma$-amino butyric acid type A.

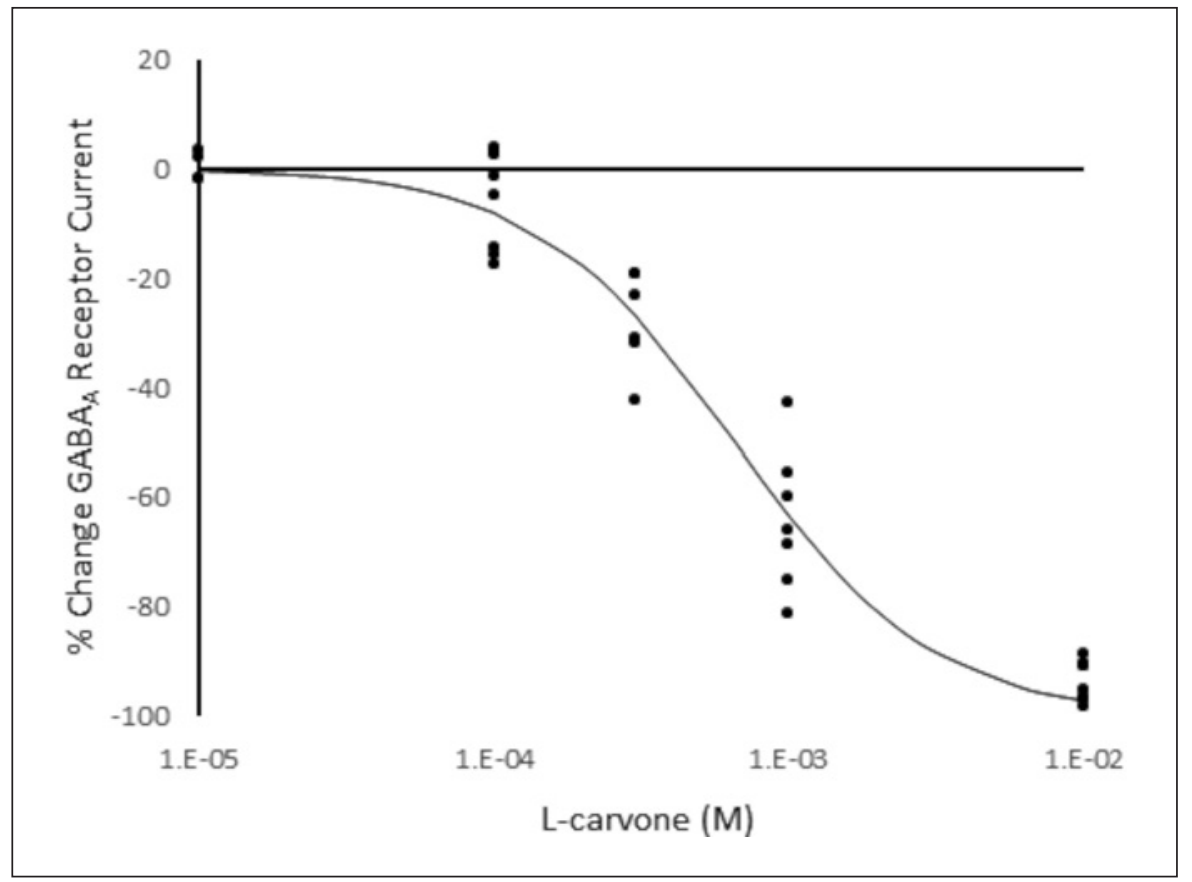

Table 1. Bootstrap parameter estimates for the nonlinear regression fit of the percent current change

\begin{tabular}{lllllll}
\hline & $I_{\max }$ & $\mathrm{IC}_{50}$ & $n_{\mathrm{I}}$ & $E_{\max }$ & $\mathrm{EC}_{50}$ & $n_{\mathrm{E}}$ \\
\hline $\begin{array}{l}\text { GABA }_{\mathrm{A}} \\
\quad \text { L-Carvone }\end{array}$ & $-100 \pm 0$ & $6.5 \mathrm{E}-4 \pm 6.5 \mathrm{E}-5$ & $1.3 \pm 0.1$ & - & - & - \\
$\quad$ Methyl salicylate & $-73 \pm 13$ & $1.1 \mathrm{E}-7 \pm 3.4 \mathrm{E}-6$ & $2.5 \pm 2.8$ & $223 \pm 34$ & $5.3 \mathrm{E}-3 \pm 8.1 \mathrm{E}-3$ & $0.21 \pm 0.06$ \\
NMDA & & & & & - \\
$\quad$ L-Carvone & $-100 \pm 0$ & $2.4 \mathrm{E}-3 \pm 4.3 \mathrm{E}-4$ & $0.8 \pm 0.1$ & - & - & - \\
$\quad \begin{array}{l}\text { Methyl salicylate } \\
\text { Nav } 1.2\end{array}$ & $-100 \pm 0$ & $2.3 \mathrm{E}-3 \pm 3.4 \mathrm{E}-4$ & $0.8 \pm 0.1$ & - & - & - \\
$\quad$ L-Carvone & $-100 \pm 0$ & $7.5 \mathrm{E}-4 \pm 1.8 \mathrm{E}-4$ & $0.9 \pm 0.5$ & - & - & - \\
$\quad$ Methyl salicylate & $-100 \pm 0$ & $1.5 \mathrm{E}-3 \pm 1.0 \mathrm{E}-4$ & $2.2 \pm 0.3$ & - & - & \\
\hline
\end{tabular}

Bootstrap parameter estimates for the nonlinear regression fit of the percent current change to the Hill equation:

$$
I_{\max } \frac{C^{n_{1}}}{\mathrm{IC}_{50}^{n_{1}}+C^{n_{1}}}+E_{\max } \frac{C^{n_{E}}}{\mathrm{EC}_{50}^{n_{E}}+C^{n_{E}}},
$$

where $I_{\max }$ and $E_{\max }$ are the respective maximum percent current inhibition or enhancement, $\mathrm{IC}_{50}$ and $\mathrm{EC}_{50}$ are the drug concentrations $C$ producing respective median inhibitory or enhancement of current, and $n_{1}$ and $n_{\mathrm{E}}$ are the respective Hill coefficients for the inhibitory and enhancing response curves

The methyl salicylate effect on GABAA receptors was described by both inhibitory and enhancement Hill equations terms. All other drug-channel interactions were only inhibitory. $G A B A_{A}, \gamma$-amino butyric acid type $A$; NMDA, N-methyl-D-aspartate; $\mathrm{Na}_{\mathrm{v}} 1.2$, type-2 voltage-gated sodium.

the sheath and auxiliary gas was 45 and 20, respectively (arbitrary units). Chromatography employed an Accucore Vanquish C18 + $10 \mathrm{~cm} \times 2.1 \mathrm{~mm} 1.5 \mathrm{~m}$ column (Thermo Scientific) and a linear gradient of $\mathrm{ACN}$ in water with a constant $0.2 \%$ formic acid at a flow rate of $0.1 \mathrm{~mL} / \mathrm{min}$. The initial ACN concentration was held at $1 \%$ for $0.4 \mathrm{~min}$ and ramped to $99 \%$ over $9 \mathrm{~min}$ before re-equilibrating for $14 \mathrm{~min}$ at initial conditions.

The precision and accuracy of the assay was determined by assaying quality control samples in replicates $(n=6)$. Accuracy was reported as percent nominal concentration and precision as per- 
Fig. 3. Linear-log plot of the percent current change from baseline of $\mathrm{GABA}_{\mathrm{A}}$ receptors exposed to methyl salicylate. Data are from 4-10 oocytes at each concentration. The solid line is the best fit to the Hill equation:

$$
-73 \frac{C^{2.5}}{\left(4.0 \times 10^{-18}\right)+C^{2.5}}+223 \frac{C^{0.21}}{(0.33)+C^{0.21}},
$$

where $C$ is the methyl salicylate concentration. $\mathrm{GABA}_{\mathrm{A}}, \gamma$-amino butyric acid type $\mathrm{A}$.

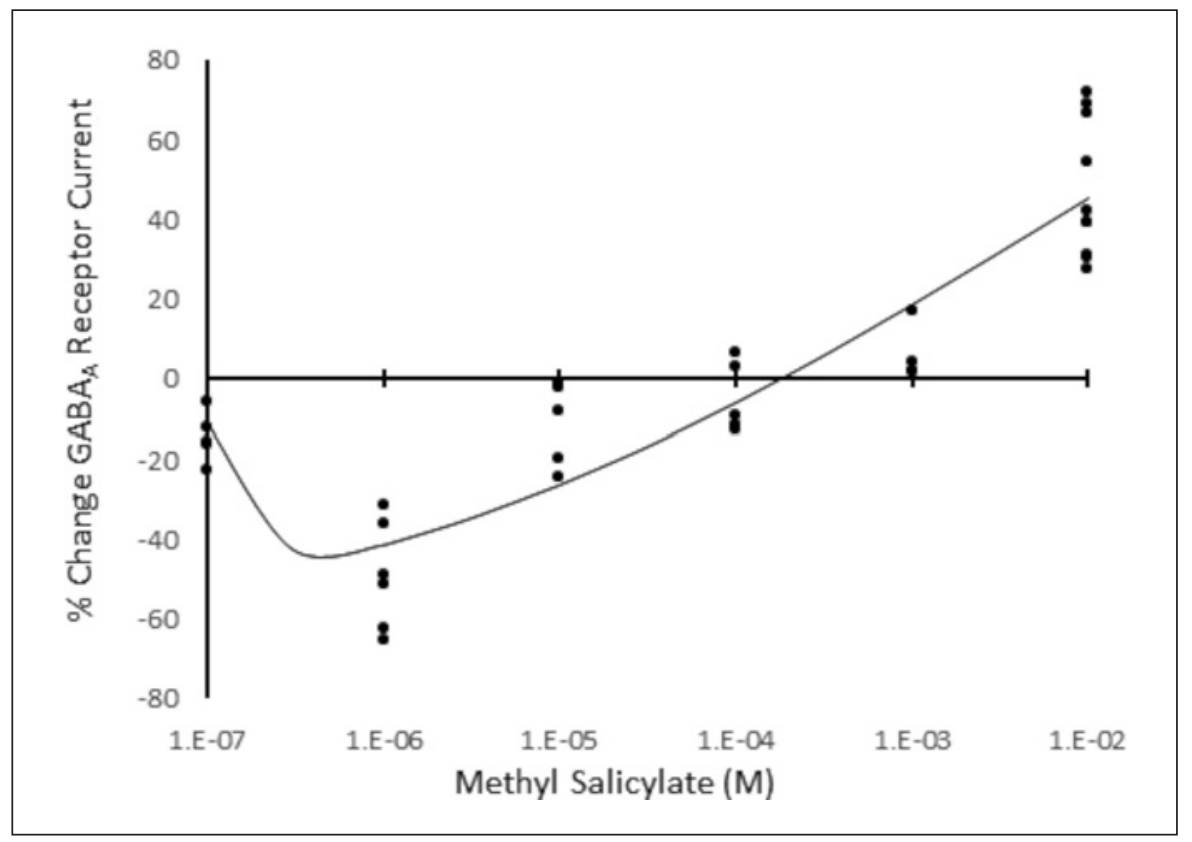

cent relative standard deviation. For both methyl salicylate and Lcarvone, all values were within $10 \%$ of the nominal concentration. The technique was optimized to provide limits of quantitation of $0.5 \mu \mathrm{g} / \mathrm{mL}$ and $0.05 \mu \mathrm{g} / \mathrm{mL}$ and limits of detection of approximately $0.1 \mu \mathrm{g} / \mathrm{mL}$ and $0.025 \mu \mathrm{g} / \mathrm{mL}$ for methyl salicylate and L-carvone, respectively.

\section{Results}

\section{In vitro Electrophysiology Studies}

Sample tracings for $\mathrm{GABA}_{\mathrm{A}}$ receptor, NMDA receptor, and $\mathrm{Na}_{\mathrm{v}} 1.2$ channel experiments are shown in Figure 1. L-Carvone caused dose-dependent inhibition of all 3 ion channels (Fig. 2, 4, 6) with near or complete loss of channel currents at the $10 \mathrm{~mm}$ drug dose. Potency of Lcarvone, as assessed by the median inhibitory concentration $\left(\mathrm{IC}_{50}\right)$ for each channel (Table 1), was ranked as follows: $\mathrm{GABA}_{\mathrm{A}} \geq \mathrm{Na}_{\mathrm{v}} 1.2>\mathrm{NMDA}$.

Methyl salicylate also dose-dependently inhibited NMDA receptors and $\mathrm{Na}_{\mathrm{v}} 1.2$ channels (Fig. 5,7 ) with the drug exhibiting $50 \%$ greater potency for the latter (Table 1). However, $\mathrm{GABA}_{\mathrm{A}}$ receptors were potently inhibited by methyl salicylate (Fig. 3) with an $\mathrm{IC}_{50}$ of $0.11 \mu \mathrm{M}$ indicative of a high-affinity receptor binding site (Table 1). At high concentrations, methyl salicylate binds a second site to potentiate $\mathrm{GABA}_{\mathrm{A}}$ currents with a median effective concentration estimated at $5.3 \mathrm{mM}$, the weakest drug-receptor interaction observed in this study.
Hill coefficient estimates for the dose-response models were close to 1 for all ion channels with $\mathrm{L}$-carvone and for NMDA receptors with methyl salicylate (Table 1). This is consistent with drug-receptor binding independent of agonist binding (in the case of $\mathrm{GABA}_{\mathrm{A}}$ and NMDA receptors) and either a single drug-protein binding site or noncooperative binding at multiple sites. The $\mathrm{Na}_{\mathrm{v}} 1.2$ doseresponse curve for methyl salicylate was significantly $>1$, suggesting cooperative binding that might occur from two or more drug molecules binding the channel at two or more interactive sites. In contrast, the Hill coefficient $<1$ for low-affinity methyl salicylate binding at the GA$\mathrm{BA}_{\mathrm{A}}$ receptor potentiation site indicates negative cooperative binding, possibly from interactions with methyl salicylate binding at the high-affinity $\mathrm{GABA}_{\mathrm{A}}$ receptor inhibitory site.

\section{In vivo Anesthesia Studies}

In the pilot study IV bolus injections, $0.2 \mathrm{~mL}$ of the $\mathrm{L}$ carvone emulsion ( $N=4$ rats) resulted in transient excitement followed by loss-of-righting reflex in $40 \pm 6 \mathrm{~s}$ and loss of tail clamp response in $54 \pm 11 \mathrm{~s}$. During this time, the respiratory rate was transiently decreased for approximately $10 \mathrm{~s}$. Half of the rats exhibited whole-body muscle hypertonia for $15 \mathrm{~s}$, after which muscles were relaxed. Recovery was rapid with righting reflex returning in $58 \pm 14$ $s$ and the rats walking and active in $60 \pm 13 \mathrm{~s}$. Body weight over the next 2 days was within $1.9 \pm 1.4$ percent of base- 
Fig. 4. Linear-log plot of the percent current change from baseline of NMDA receptors exposed to L-carvone. Data are from 5-7 oocytes at each concentration. The solid line is the best fit to the Hill equation:

$-100 \frac{C^{0.8}}{\left(8.0 \times 10^{-3}\right)+C^{0.8}}$,

where $C$ is the $\mathrm{L}$-carvone concentration. NMDA, N-methyl-D-aspartate.

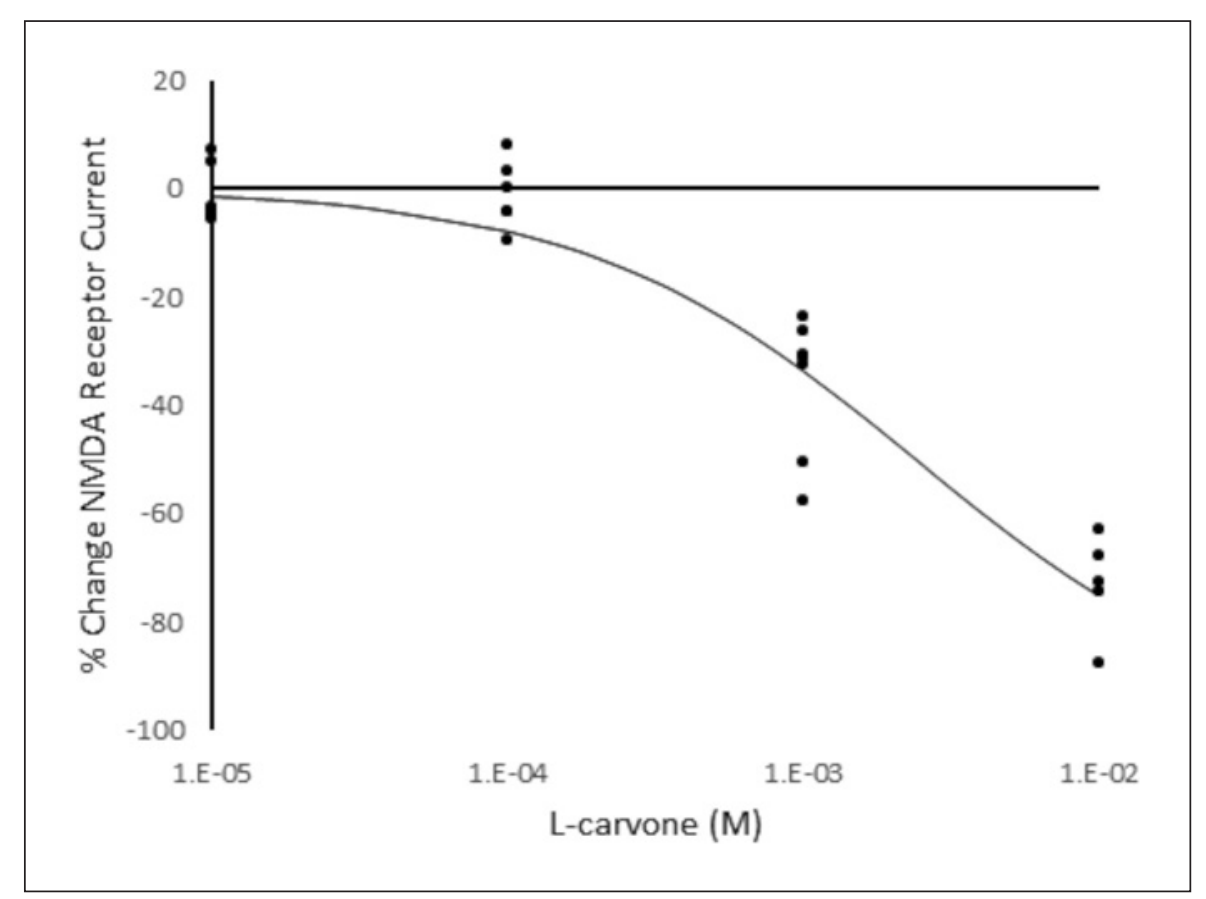

line, and no gross pathology findings were noted on examination of the heart, lung, liver, or kidney. Similar intravenous injection of $0.4 \mathrm{~mL}$ of L-carvone ( $N=4$ rats) induced unconsciousness and flaccid muscle tone in $20 \pm$ $4 \mathrm{~s}$ and cardiopulmonary arrest in $35 \pm 18 \mathrm{~s}$.

A $0.1 \mathrm{~mL}$ IV bolus of the methyl salicylate emulsion in a single rat caused loss- and return-of-righting reflex in 33 and $60 \mathrm{~s}$, respectively, but never resulted in general anesthesia, as defined by immobility in response to a tail clamp. Increasing the methyl salicylate injection dose to $0.15 \mathrm{~mL}$ ( $N=4$ rats) caused loss-of-righting in $35 \pm 5 \mathrm{~s}$ and anesthesia in $39 \pm 2 \mathrm{~s}$, and both returned in $53 \pm 3$ and $64 \pm 8$ $s$ after drug injection with normal ambulation without ataxia at $76 \pm 10 \mathrm{~s}$. Following a $0.2 \mathrm{~mL}$ methyl salicylate emulsion injection ( $N=3$ rats), loss-of-righting and general anesthesia occurred in $35 \pm 10$ and $37 \pm 13 \mathrm{~s}$, respectively. However, 1 rat exhibited cardiopulmonary arrest $35 \mathrm{~s}$ following this dose of methyl salicylate. The other 2 rats regained tail clamp and righting responses an average of $48 \mathrm{~s}$ and $58 \mathrm{~s}$, respectively, and were ambulating normally $110 \mathrm{~s}$ following drug administration. For those rats receiving sublethal methyl salicylate doses, body weight was within $97-98 \%$ of baseline values for the next two days, and no gross abnormalities were found on necropsy $48 \mathrm{~h}$ after drug administration. Increasing the methyl salicylate emulsion dose to $0.4 \mathrm{~mL}$ ( $N=3$ rats) resulted in unconsciousness in $20 \pm 5 \mathrm{~s}$ and cardiopulmonary arrest in all animals $31 \pm \mathrm{sec}$ after beginning injection.
Co-administration of $0.1 \mathrm{~L}$-carvone emulsion plus 0.1 $\mathrm{mL}$ methyl salicylate emulsion $(N=2$ rats) produced almost identical signs over a similar time scale as the anesthetic doses of described for either L-carvone emulsion or methyl salicylate emulsion administered alone. Body weights for both animals over the next 2 days ranged between 98 and $101 \%$ of baseline, and necropsy examinations were unremarkable. As there was no obvious benefit to this combination over administration of only the single agent, the pharmacodynamics of L-carvone/methyl salicylate mixtures were not further evaluated.

Continuous $0.2 \mathrm{~mL} / \mathrm{min}$ IV infusions of L-carvone emulsions produced muscle fasciculations and loss-ofrighting reflex followed by tonic muscle contractions suggestive of seizure over 2-4 min after the start of injection. After this time, there was no response to toe pinch and tail clamp, and the animals were euthanized by exsanguination. Similar injection with methyl salicylate emulsions in rats caused transient excitement in half of the animals $30 \mathrm{~s}$ after injection. Loss-of-righting and absent tail clamp responses occurred within 3-4 min after start of injection, after which rats were euthanized by exsanguination. No tonic or clonic muscle activity was observed in any rat administered methyl salicylate infusions.

The mean plasma concentration $( \pm$ SEM) of L-carvone during IV infusion in rats $(N=4)$ was $7.9 \pm 3.0 \mathrm{mM}(N=$ 4). This concentration of L-carvone corresponded to $96 \%$ inhibition of $\mathrm{GABA}_{\mathrm{A}}$ receptors (Fig. 2), 71\% inhibition of 
Fig. 5. Linear-log plot of the percent current change from baseline of NMDA receptors exposed to methyl salicylate. Data are from 5-7 oocytes at each concentration. The solid line is the best fit to the Hill equation:

$$
-100 \frac{C^{0.8}}{\left(7.7 \times 10^{-3}\right)+C^{0.8}},
$$

where $C$ is the methyl salicylate concentration. NMDA, N-methyl-D-aspartate.

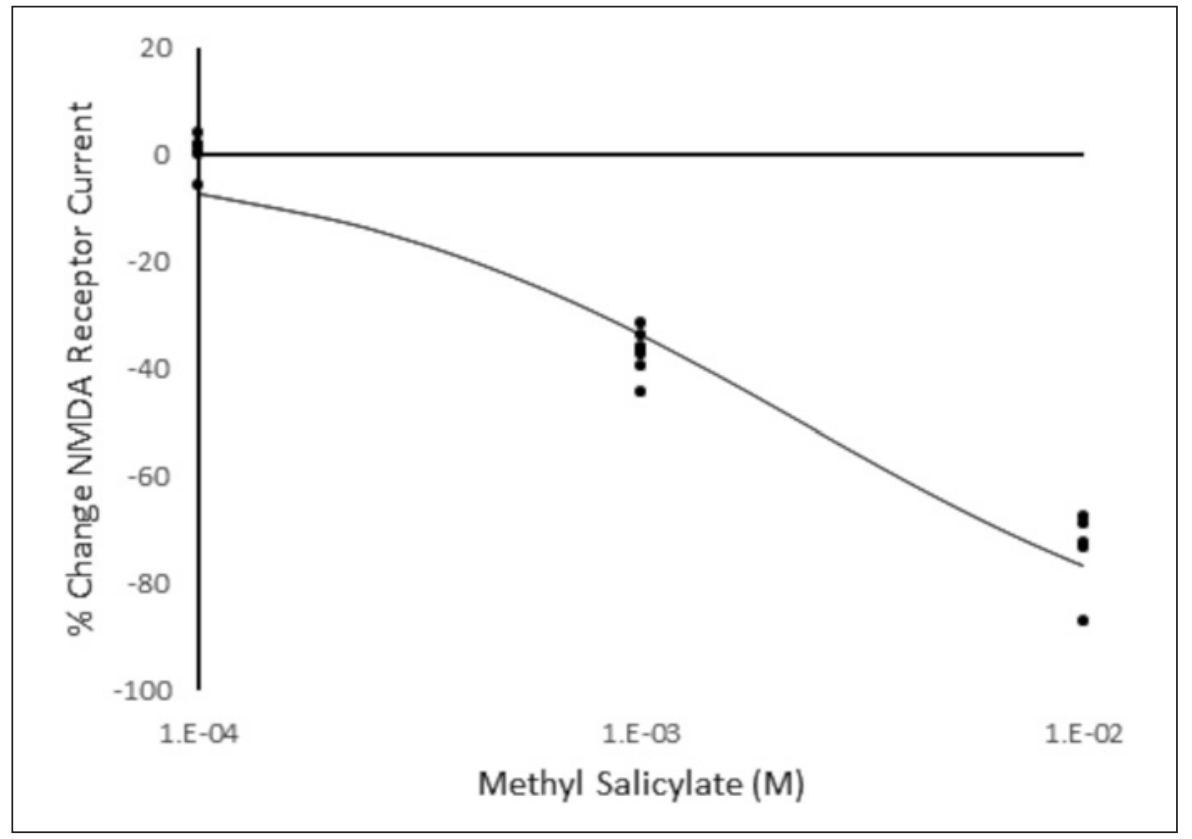

NMDA receptors (Fig. 4), and 90\% inhibition of $\mathrm{Na}_{\mathrm{v}} 1.2$ channels (Fig. 6) for in vitro electrophysiology studies. Methyl salicylate concentration during IV infusions in rats $(N=4)$ was $2.7 \pm 0.4 \mathrm{mM}$. This methyl salicylate concentration was associated with $30 \%$ potentiation of GA$\mathrm{BA}_{\mathrm{A}}$ receptors (Fig. 3), 53\% inhibition of NMDA receptors (Fig. 5), and $78 \%$ inhibition of $\mathrm{Na}_{\mathrm{v}} 1.2$ channels (Fig. 7) in vitro.

\section{Discussion}

Amphipathic compounds with sufficient molar water solubility can modulate anesthetic-sensitive ion channels such as $\mathrm{GABA}_{\mathrm{A}}$ receptors, NMDA receptors, and $\mathrm{Na}_{\mathrm{v}} 1.2$ channels via low-affinity interactions, often at hundreds of micromolar concentrations or higher. The mint compounds L-carvone and methyl salicylate are more soluble in water than the cutoff values for modulation of these 3 anesthetic-sensitive ion channels $[4,5]$. We have shown that both mint compounds do indeed modulate $\mathrm{GABA}_{\mathrm{A}}$ receptor, NMDA receptor, and $\mathrm{Na}_{\mathrm{v}} 1.2$ channel currents at concentrations associated with general anesthesia in rats.

L-Carvone application to the sciatic nerve axon of frogs decreases compound action potential amplitude with an $\mathrm{IC}_{50}$ of $1.4 \mathrm{mM}$ [14]. This is similar to the $\mathrm{IC}_{50}$ for human $\mathrm{Na}_{\mathrm{v}} 1.2$ channels in the present study (Table 1). Given the central role of nodal $\mathrm{Na}_{\mathrm{v}} 1.2$ channels for action potential propagation along nerve axons, results support a local anesthetic mechanism of drug action. L-Carvone also decreases compound action potentials in rat sciatic nerves, but at an $\mathrm{IC}_{50}$ of $8.7 \mathrm{~mm}$ [15]. This potency variability suggests significant species differences in drug-receptor binding affinity.

A previous 2-electrode voltage clamp study of human benzodiazepine-sensitive $\alpha_{1} \beta_{2} \gamma_{2 s}$ GABA $_{A}$ receptors expressed in frog oocytes showed minimal response to Lcarvone concentrations up to $0.12 \mathrm{mM}$ [16]. In rat cerebral cortex cell cultures, $0.75 \mathrm{mML}$-carvone exerted a negativeallostericeffectwith $\mathrm{GABA}_{\mathrm{A}}$-inducedbenzodiazepine binding reduced by $36 \%$ [17]. However, even greater GA$\mathrm{BA}_{\mathrm{A}}$ receptor modulation occurs at higher L-carvone concentrations. $\mathrm{GABA}_{\mathrm{A}}$ receptor currents were almost entirely inhibited by $10 \mathrm{mML}$-carvone, the highest concentration studied here.

Mint oils have been used as immersion anesthetics in fish. Baths containing either 1.9-4.5 mML-carvone or 0.8$2.3 \mathrm{~mm}$ methyl salicylate caused anesthesia in carp with the highest doses associated with faster onset and longer recovery times [18]. Co-administration of the 2 mint extracts as an emulsion reduced the concentration required for each drug by $75 \%$ suggesting possible drug synergy action, at least in fish $[19,20]$. The rat pilot experiments reported here with L-carvone, methyl salicylate, and the 1:1 administration of both compounds did not show as obvious a difference in dose requirement, onset of action, or recovery time. These similar anesthetic effects reflect 
Fig. 6. Linear-log plot of the percent current change from baseline of type- 2 voltage-gated sodium channels exposed to Lcarvone. Data are from 3-7 oocytes at each concentration. The solid line is the best fit to the Hill equation:

$-100 \frac{C^{0.9}}{\left(1.5 \times 10^{-3}\right)+C^{0.9}}$,

where $C$ is the $\mathrm{L}$-carvone concentration.
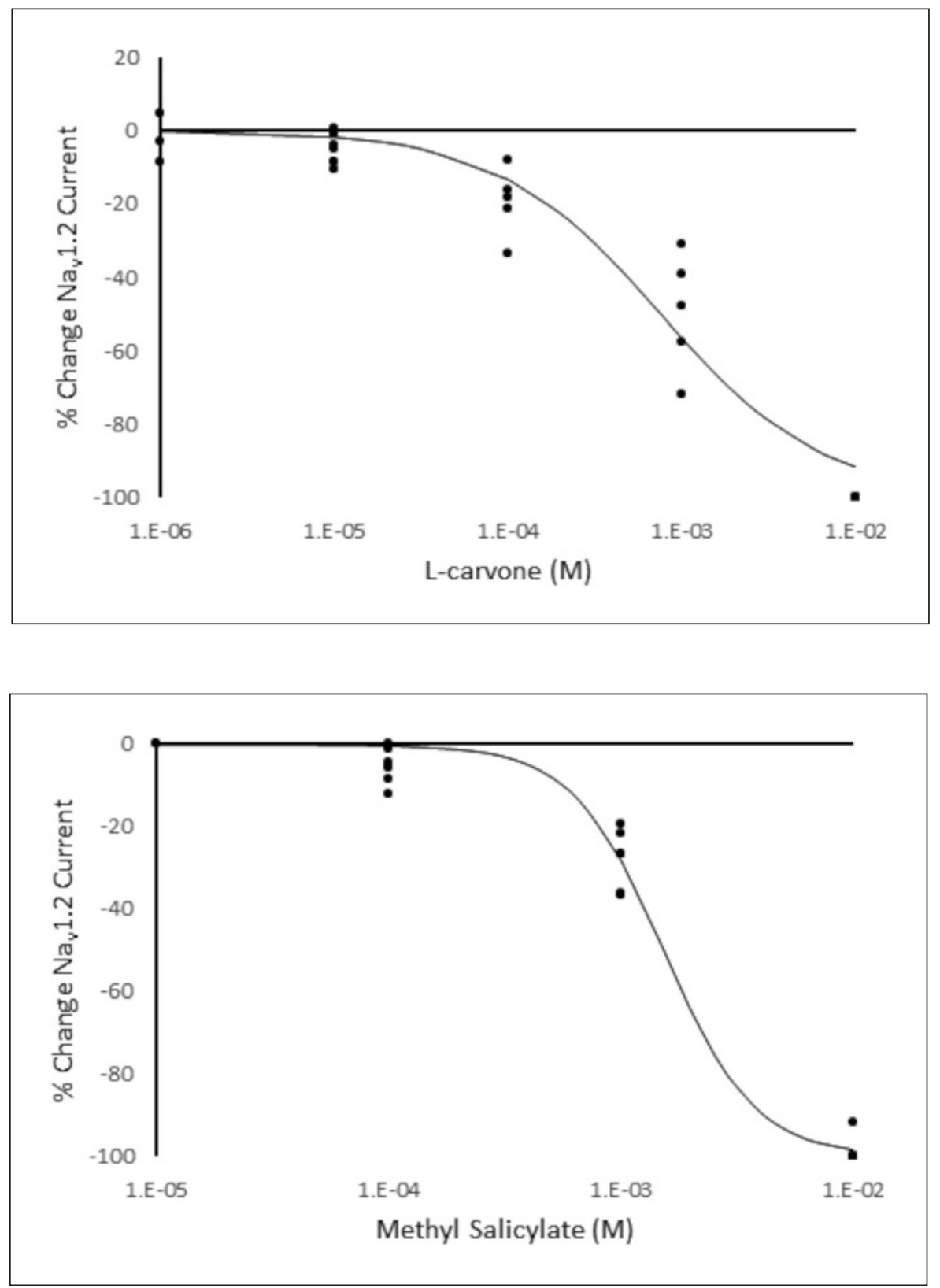

Fig. 7. Linear-log plot of the percent current change from baseline of type- 2 voltage-gated sodium channels exposed to methyl salicylate. Data are from 6-9 oocytes at each concentration. The solid line is the best fit to the Hill equation:

$-100 \frac{C^{2.2}}{\left(6.1 \times 10^{-7}\right)+C^{2.2}}$,

where $C$ is the methyl salicylate concentration. similar receptor drug actions and potency at NMDA receptors and $\mathrm{Na}_{\mathrm{v}} 1.2$ channels.

The one remarkable difference in the mechanism of action between mint extracts occurred at the $\mathrm{GABA}_{\mathrm{A}}$ receptor. However, L-carvone caused dose-dependent inhibition, and methyl salicylate exhibited a biphasic effect on $\mathrm{GABA}_{\mathrm{A}}$ receptor currents (Fig. 2, 3). This implies the presence of at least 2 separate salicylate ester allosteric binding sites on the $\mathrm{GABA}_{\mathrm{A}}$ receptor. Negative allosteric modulation occurred at a high-affinity binding site with an $\mathrm{IC}_{50}$ of approximately $0.1 \mu \mathrm{M}$ methyl salicylate. This site may be the same $\mathrm{GABA}_{\mathrm{A}}$ binding site as for the highaffinity anesthetic ligands propofol and propanidid, which share structural similarities to L-carvone and methyl salicylate [6]. At about 50,000 times higher concentration, methyl salicylate binds a second, noncompetitive positive allosteric site that, at a saturated aqueous phase concentration, produced a predicted $\mathrm{GABA}_{\mathrm{A}}$ current potentiation to equal to half of the maximum observable enhancement possible with the agonist concentration used in this study. This binding site may be similar to the amphipathic, water-filled, allosterically active 
pockets predicted for low-affinity interactions with inhaled anesthetics and other simple hydrocarbons $[4,5]$.

$\mathrm{GABA}_{\mathrm{A}}$ receptor potentiation typically causes central nervous system depression; $\mathrm{GABA}_{\mathrm{A}}$ receptor inhibition causes convulsions [21]. During anesthesia maintenance, L-carvone caused tonic muscle contractions suggestive of seizure activity at concentrations corresponding to near total inhibition of $\mathrm{GABA}_{\mathrm{A}}$ receptor currents. Although methyl salicylate also inhibits these same currents at low concentrations, a rapid rise in plasma drug concentration to agonist levels during IV administration probably circumvented seizures in these rats. Additionally, inhibition of glutamate receptors and sodium channel currents decreases neuronal excitability and may have stopped seizure activity during L-carvone anesthesia and prevented visible seizures following high-dose bolus euthanasia in pilot rat experiments [22].

Differences between mint extract effects on $\mathrm{GABA}_{\mathrm{A}}$ receptors may also explain differences in drug potency. $\mathrm{GABA}_{\mathrm{A}}$ receptor inhibition increases neuronal excitability and increases anesthetic median effective concentrations [23]. Presumably, this is because increased basal excitability must be overcome through more depressant effects at other anesthetic-sensitive receptor targets, such as from NMDA receptor inhibition [24]. At the time general anesthesia was achieved and the aorta catheterized, plasma concentration of L-carvone was 3 times that for methyl salicylate and corresponded to $\mathrm{GABA}_{\mathrm{A}}$ receptor inhibition for $\mathrm{L}$-carvone but $\mathrm{GABA}_{\mathrm{A}}$ receptor potentiation for methyl salicylate. $\mathrm{GABA}_{\mathrm{A}}$ receptors would therefore contribute to methyl salicylate anesthesia but antagonize L-carvone anesthesia. These higher L-carvone plasma concentrations during anesthesia equate to $15-30 \%$ greater inhibition of NMDA receptors and $\mathrm{Na}_{\mathrm{v}} 1.2$ channels than was present at the methyl salicylate plasma concentrations (Fig. 4-7). Increased action at these and perhaps other receptor targets allows L-carvone to induce an anesthesia effect despite contrary activity at $\mathrm{GABA}_{\mathrm{A}}$ receptors. Indeed, a similar phenomenon has been described for conventional anesthetics, such as the inhaled agents isoflurane and sevoflurane that exhibit low-affinity interactions with structurally diverse anesthetic-sensitive ion channels and receptors. Antagonism of spinal $\mathrm{GABA}_{\mathrm{A}}$ receptors in rats increases the isoflurane $\mathrm{EC}_{50}$ for immobilization by up to $40 \%$ [23]. However, isoflurane requirement is not greater with further $\mathrm{GABA}_{\mathrm{A}}$ receptor inhibition, presumably because increased isoflurane concentrations produce increased effects at other molecular targets - such as NMDA receptors [25], voltage-gated sodium channels [26], 2-pore domain potassium channels
[27], and glycine receptors [28] - that combined are sufficient to depress CNS function and cause immobility. Similarly, antagonism of spinal glycine receptors in rats increases the sevoflurane $\mathrm{EC}_{50}$, at which general anesthesia is mediated by greater inhibition of NMDA receptors produced by this greater sevoflurane concentration [29].

The present study focused on an anesthetic endpoint, but these same receptor systems exert other important neurophysiologic effects. Sodium channel blockers and glutamate receptor antagonists act at sites within both the peripheral and central nervous system where they decrease pain [22]. In addition, both mint extracts can modulate other anesthetic-sensitive ion channels important for analgesia, such as the transient receptor potential cation channel TRPV1 $[30,31]$. It is possible that antinociceptive effects may be achieved at subanesthetic drug concentrations.

Like L-carvone and methyl salicylate, conventional volatile anesthetics modulate anesthetic-sensitive ion channels through low-affinity interactions. However, conventional volatile anesthetics are not natural compounds, so why should these or other amphipathic compounds modulate anesthetic-sensitive ion channels at all? It has been proposed that pervasive environmental exposure to amphipathic chemicals from the beginnings of life to the present creates selective pressures for ion channels to decrease cation currents or increase anion currents in order to prevent uncontrolled and deleterious cell depolarization [32]. Indeed, animals are awash in potential anesthetic-acting compounds such as ammonia [33], amino acids [34], ketones [35], carboxylic acids [36], carbon dioxide $[37,38]$, and even the nitrogen in air itself $[39,40]$. Among plants, L-carvone and methyl salicylate are just two of at least several dozen terpenoids and salicylate esters with molar water solubility values sufficient to predict activity on anesthetic-sensitive ion channels and receptors. However, $\mathrm{GABA}_{\mathrm{A}}$ receptor inhibition by plant terpenoids and salicylate esters can increase cell excitability and suggests there may not be selective pressure in favor of any particular directional channel response to anesthetic-like compounds. Rather, the concentrationresponse data reported here for mint compounds, as well as previously for other metabolites and gases, indicate there may be selective pressure for anesthetic-sensitive ion channel insensitivity to amphipathic compounds at concentrations commonly present in the environment or internal milieu. It is only because channels are unresponsive to these low concentrations that, in the words of Shakespeare, we can "shake off this downy sleep." 


\section{Conclusions}

As predicted by their molar water solubility values, the mint extracts L-carvone and methyl salicylate modulate $\mathrm{GABA}_{\mathrm{A}}$ receptor, NMDA receptor, and $\mathrm{Na}_{\mathrm{v}} 1.2$ channel currents at millimolar concentrations indicative of lowaffinity drug-ligand binding. Furthermore, drug concentrations associated with anesthetic-sensitive ion channel effects also induce anesthesia in rats. It is possible that these or similar edible terpenoids and salicylate esters may offer utility as injectable anesthetic, analgesic, or euthanasia agents in animals, particularly in livestock where drug residues may be of concern.

\section{Statement of Ethics}

All animal work was conducted with approval by the Institutional Animal Care and Use Committee at the University of California, Davis (Protocol No. 21535 and 21559).

\section{Conflict of Interest Statement}

Dr. Brosnan has assigned a provisional patent to the University of California related to the use of food-derived terpenoids and salicylate esters as injectable anesthetic, analgesic, and euthanasia agents. Other authors report no conflicts of interest.

\section{Funding Sources}

This work was supported using funds from the Department of Surgical and Radiological Sciences at the University of California, Davis.

\section{Author Contributions}

Brosnan conceived the project, designed studies, participated in data acquisition, analyzed and interpreted data, and wrote the manuscript draft. Ramos participated in data acquisition, assisted with data analysis, and reviewed the manuscript. Aguiar participated in data acquisition, assisted with data analysis, and reviewed the manuscript. Cenani participated in data acquisition, assisted with data analysis, and reviewed the manuscript. Knych participated in data acquisition, assisted with data analysis, and reviewed the manuscript.

\section{Data Availability Statement}

Computer files containing experimental measurements used for the data summaries and analyses of this study are available at Dryad (doi:10.25338/B8463X).

\section{References}

1 Brosnan RJ, Steffey EP. Inhalation anesthetics. In: Riviere JE, Papich MG, editors. Veterinary pharmacology and therapeutics. 10th ed. Hoboken, NJ: John Wiley \& Sons; 2018. p. $216-46$.

2 Steffey EP, Mama KR, Brosnan RJ. Inhalation anesthetics. In: Grimm KA, Lamont LA, Tranquilli WJ, Greene SA, Robertson SA, editors. Veterinary anesthesia and analgesia. 5th ed. Ames, IA: John Wiley \& Sons; 2015. p. 297-331.

3 Brosnan RJ, Pham TL. GABAA receptor modulation by phenyl ring compounds is associated with a water solubility cut-off value. Pharmacology. 2016;98(1-2):13-9.

4 Brosnan RJ, Pham TL. Hydrocarbon molar water solubility predicts NMDA vs. GABAA receptor modulation. BMC Pharmacol Toxicol. 2014;15:62.

5 Brosnan RJ, Pham TL. Anesthetic-sensitive ion channel modulation is associated with a molar water solubility cut-off. BMC Pharmacol Toxicol. 2018;19(1):57.

6 Tsuchiya $\mathrm{H}$. Anesthetic agents of plant origin: a review of phytochemicals with anesthetic activity. Molecules. 2017;22(8):1369.
7 Duthie GG, Wood AD. Natural salicylates: foods, functions and disease prevention. Food Funct. 2011;2(9):515-20.

8 Brosnan R, Gong D, Cotten J, Keshavaprasad B, Yost CS, Eger EI 2nd, et al. Chirality in anesthesia II: stereoselective modulation of ion channel function by secondary alcohol enantiomers. Anesth Analg. 2006;103(1):86-91.

9 Yang L, Milutinovic PS, Brosnan RJ, Eger EI 2nd, Sonner JM. The plasticizer di(2-ethylhexyl) phthalate modulates gamma-aminobutyric acid type $A$ and glycine receptor function. Anesth Analg. 2007;105(2):393-6.

10 Brosnan RJ, Fukushima FB, Pham TL. Anesthetic synergy between two n-alkanes. Vet Anaesth Analg. 2017;44(3):577-88.

11 Cenani A, Brosnan RJ, Knych HK. In vitro and in vivo GABAA receptor interaction of the propanidid metabolite 4-(2-[diethylamino]-2-oxoethoxy)-3-methoxy-benzeneacetic acid. Pharmacology. 2019;103(1-2):10-6.

12 Royals EE, Horne SE. Conversion of d-limonene to 1-carvone. J Am Chem Soc. 1951; 73(12):5850-6.
13 Glowaski RC, Lynch CC. Densities of mixtures of benzene with phenylethyl alcohol and with methyl salicylate. J Am Chem Soc. 1933; 55(10):4051-2.

14 Ohtsubo S, Fujita T, Matsushita A, Kumamoto $\mathrm{E}$. Inhibition of the compound action potentials of frog sciatic nerves by aroma oil compounds having various chemical structures. Pharmacol Res Perspect. 2015;3(2): e00127.

15 Goncalves JC, Alves Ade M, de Araujo AE, Cruz JS, Araujo DA. Distinct effects of carvone analogues on the isolated nerve of rats. Eur J Pharmacol. 2010;645(1-3):10812.

16 Hall AC, Turcotte CM, Betts BA, Yeung WY, Agyeman AS, Burk LA. Modulation of human GABAA and glycine receptor currents by menthol and related monoterpenoids. Eur J Pharmacol. 2004;506(1):9-16.

17 Sanchez-Borzone M, Delgado-Marin L, Garcia DA. Inhibitory effects of carvone isomers on the GABAA receptor in primary cultures of rat cortical neurons. Chirality. 2014;26(8): $368-72$. 
18 Roohi Z, Imanpoor MR. The efficacy of the oils of spearmint and methyl salicylate as new anesthetics and their effect on glucose levels in common carp (Cyprinus carpio L., 1758) juveniles. Aquaculture. 2015;437:327-32.

19 Roohi Z, Imanpoor MR. Effects of spearmint (L-carvon) oil and methyl salicylate oil emulsion on anesthesia of common carp (Cyprinus carpio L., 1758). J Aquac Res Development. 2014;5(2):1-5.

20 Danner GR, Muto KW, Zieba AM, Stillman CM, Seggio JA, Ahmad ST. Spearmint (l-carvone) oil and wintergreen (methyl salicylate) oil emulsion is an effective immersion anesthetic of fishes. J Fish Wildl Manag. 2011;2(2): 146-55.

21 Eger EI 2nd, Koblin DD, Sonner J, Gong D, Laster MJ, Ionescu P, et al. Nonimmobilizers and transitional compounds may produce convulsions by two mechanisms. Anesth Analg. 1999;88(4):884-92.

22 Nestler EJ, Kenny PJ, Russo SJ, Shaefer A. Molecular neuropharmacology: a foundation for clinical neuroscience. 4th ed. New York, NY: McGraw-Hill; 2020. p. 608.

23 Zhang Y, Stabernack C, Sonner J, Dutton R, Eger EI 2nd. Both cerebral GABA(A) receptors and spinal $\mathrm{GABA}(\mathrm{A})$ receptors modulate the capacity of isoflurane to produce immobility. Anesth Analg. 2001;92(6):1585-9.

24 Brosnan RJ. GABA(A) receptor antagonism increases NMDA receptor inhibition by isoflurane at a minimum alveolar concentration. Vet Anaesth Analg. 2011;38(3):231-9.
25 Yang J, Zorumski CF. Effects of isoflurane on $\mathrm{N}$-methyl-D-aspartate gated ion channels in cultured rat hippocampal neurons. Ann N Y Acad Sci. 1991;625:287-9.

26 Shiraishi M, Harris RA. Effects of alcohols and anesthetics on recombinant voltage-gated $\mathrm{Na}+$ channels. J Pharmacol Exp Ther. 2004;309(3):987-94.

27 Patel AJ, Honoré E, Lesage F, Fink M, Romey G, Lazdunski M. Inhalational anesthetics activate two-pore-domain background $\mathrm{K}+$ channels. Nat Neurosci. 1999;2(5):422-6.

28 Downie DL, Hall AC, Lieb WR, Franks NP. Effects of inhalational general anaesthetics on native glycine receptors in rat medullary neurones and recombinant glycine receptors in Xenopus oocytes. Br J Pharmacol. 1996; 118(3):493-502.

29 Brosnan RJ, Thiesen R. Increased NMDA receptor inhibition at an increased sevoflurane MAC. BMC Anesthesiol. 2012;12(1):9.

30 Goncalves JC, Silveira AL, de Souza HD, Nery AA, Prado VF, Prado MA, et al. The monoterpene (-)-carvone: a novel agonist of TRPV1 channels. Cytometry A. 2013;83(2):212-9.

31 Ohta $\mathrm{T}$, Imagawa $\mathrm{T}$, Ito $\mathrm{S}$. Involvement of transient receptor potential vanilloid subtype $1 \mathrm{in}$ analgesic action of methylsalicylate. Mol Pharmacol. 2009;75(2):307-17.

32 Sonner JM. A hypothesis on the origin and evolution of the response to inhaled anesthetics. Anesth Analg. 2008;107(3):849-54.

33 Brosnan RJ, Yang L, Milutinovic PS, Zhao J, Laster MJ, Eger EI 2nd, et al. Ammonia has anesthetic properties. Anesth Analg. 2007; 104(6):1430-3.
34 Milutinovic PS, Yang L, Cantor RS, Eger EI 2nd, Sonner JM. Anesthetic-like modulation of a gamma-aminobutyric acid type A, strychnine-sensitive glycine, and N-methyl-d-aspartate receptors by coreleased neurotransmitters. Anesth Analg. 2007;105(2):386-92.

35 Yang L, Zhao J, Milutinovic PS, Brosnan RJ, Eger EI 2nd, Sonner JM. Anesthetic properties of the ketone bodies beta-hydroxybutyric acid and acetone. Anesth Analg. 2007;105(3): 673-9.

36 Weng Y, Hsu TT, Zhao J, Nishimura S, Fuller GG, Sonner JM. Isovaleric, methylmalonic, and propionic acid decrease anesthetic EC50 in tadpoles, modulate glycine receptor function, and interact with the lipid 1,2-dipalmitoyl-Sn-glycero-3-phosphocholine. Anesth Analg. 2009;108(5):1538-45.

37 Brosnan RJ, Eger EI 2nd, Laster MJ, Sonner JM. Anesthetic properties of carbon dioxide in the rat. Anesth Analg. 2007;105(1):103-6.

38 Brosnan RJ, Pham TL. Carbon dioxide negatively modulates N-methyl-D-aspartate receptors. Br J Anaesth. 2008;101(5):673-9.

39 Winter PM, Bruce DL, Bach MJ, Jay GW, Eger EI 2nd. The anesthetic effect of air at atmospheric pressure. Anesthesiology. 1975;42(6): 658-61.

40 Koblin DD, Fang Z, Eger EI 2nd, Laster MJ, Gong D, Ionescu P, et al. Minimum alveolar concentrations of noble gases, nitrogen, and sulfur hexafluoride in rats: helium and neon as nonimmobilizers (nonanesthetics). Anesth Analg. 1998;87(2):419-24. 